San Antonio Review • San Antonio Review (No. 5, Summer 2021)

\title{
Forgetting Mariam
}

\section{Maxim Matusevich}

Published on: Mar 03, 2021

License: Creative Commons Attribution 4.0 International License (CC-BY 4.0). 


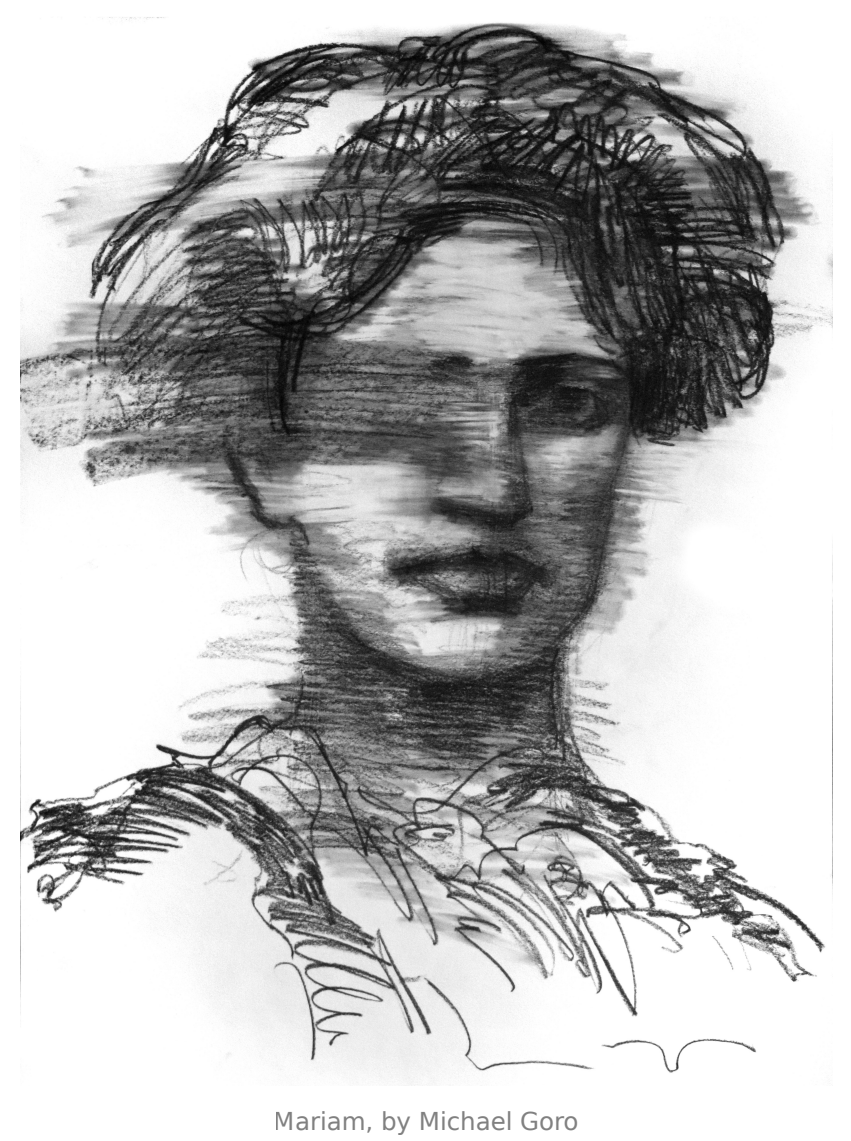

"Did it hurt?" He made an effort to sound tender. They were spooning after sex and she took his question for pillow talk.

“Hurt? You silly. I'm just noisy. It didn't hurt at all. It was nice." Playfully, she pressed her buttocks into his groin - a lighthearted sign of no regrets harbored. "It was really nice. Did you know that by touching a man with her bare butt, a woman signals trust?"

She was full of such little wisdoms. He couldn't see her face but knew that she was smiling, a sly and contented smile of a woman flattered by her lover's concern. Her lover, her man... well, that was an overstatement. To say the least. But at the moment, at that early morning moment it did feel like they belonged to each other. One-night stands can be like that - deceptively intimate, out-of-thin-air immediate. "Instant coffee, one-day mayflies, or, if you prefer a cliché (which I know you always do), a flash in a pan," that's how his ex, Lisa, talked about her own past casual hook-ups.

Lisa's sarcasm drove him mad and eventually drove him away. At least, that was the convenient explanation he came up with and then perfected in the course of numerous faux-therapy, post-break up sessions with his friends and occasional lovers. She drove 
him away, which really meant that he was a coward and a weakling - an unpleasant, but easily provable fact that Lisa never failed to bring up in their increasingly rare phone conversations. It was an amicable divorce and as such a source of some pride for both of them. "What could be more civilized," Lisa quipped, "than parting ways like true adults?" He agreed, but a divorce is still a divorce and once in a while a thought of Lisa made him wince - as if someone pricked at a tender spot with a tiny safety pin. And presently he promptly felt that quick pinprick, but it only lasted for a second, halfa-second to be precise, and the discomfort was gone before he'd been able to process it.

Not now - now was different, now he was lying in bed next to Mariam, her trusting butt pushed up against his wooly lower stomach, his right arm over her side, slipped through under the warm armpit (Lisa's voice again: "Remember how back in childhood they would stick a thermometer under your arm? Remember how you were desperate for the mercury to hit the magic 37 degrees and then move just above the fateful red dot? You got a fever, sweetie, no school tomorrow. Oh, the joy, the happiness of having a fever!"), his hand cupping the fullness of her breast, its nipple flattened innocently against his palm. He was hugging her so closely that his lips touched the small of her neck, he felt his nose tickled by a coarse wayward curl that had broken out of her black frizz, also tickled by a barely perceptible and still unfamiliar odor of her post-love sweat.

Mariam laughed: “Hurt?! Oh my, it's like you're not Russian anymore. They must've added something to your water in America. Or what is it you drink over there? Coke? Budweiser? Whatever it is - you have stopped being a Russian man. You even made love like a polite foreigner. Next thing I know you'll start speaking Italian with me. I once had a fling with an Italian guy. On Cyprus. Just as sweet before sex as after. Not Russians though, oh no, sir, not Russians. Our guys, they just come and go... if you know what I mean."

\section{“What about Armenians?"}

“How would I know? I never slept with an Armenian. My daughter's father, by the way, was Jewish - just like you. You know what my grandma used to say about Jews and Armenians? No? Get this: we, Armenians, should always take care of the Jews. You know why? No? Because if there are no Jews left the world will notice that we're next on the list. Funny, don't you think? My grandma was a riot!” 
Tenderness - effortless now. But how real? He was old enough to know that about himself - that instant attachment to the immediate, the fleeting intimacy with a stranger, a 'perfect stranger' as they said in the movies. Only in this case the cliché didn't work. Mariam laid no claims to perfection and she was hardly a stranger. Not exactly a stranger - they probably said that in the movies too. Mariam shifted, adjusting more snugly to the shape of his body, and once again he sensed her smile:

“Look at you. Getting hard again, my little childhood friend?”

No, not a friend, not really. Neither a stranger nor a friend. Their shared childhood was a myth - to a point, of course, as there is a kernel of truth to any myth. That obsessive German, Heinrich Schliemann, found his Troy precisely because he trusted a myth, was guided by it, in fact. Schliemann quite literally unearthed Homer's Troy (or what he took for Homer's Troy, anyway), but $H E$ - he had not been looking for Mariam, having little interest in artefacts of memory. He had managed to lead a life free of such pursuits, and fairly successfully so... to a point. Lisa used to fault him for this lack of curiosity. "Painfully unimaginative," he overheard her once describing him over the phone to a girlfriend in Belgium. At least he assumed she was describing him. At the time he thought she was being unfair, but, grudgingly, he had to admit to himself that Lisa's disdain for him was not entirely baseless. Unfair and cruel - yes, but hardly baseless. And now again, with his lips touching Mariam's round shoulder, his hands cradling her breasts, he felt far removed from the original myth of their relationship he cared about it as little as he did about the hulk of that lost ark, resting forlornly on the gradient of an Armenian mountain. He was no Heinrich Schliemann, and he didn't discover her on a mountain slope - the day before, he ran into her on Nevsky prospect. You always run into someone on Nevsky - it's one of its well-publicized and much-written-about oddities.

She recognized him first and having assessed quickly his state of incomprehension, proceeded to tease him affably:

“No, I'm not your college girlfriend. Actually, not an ex at all, so you can relax. Breathe in and out. Think harder. I can't believe you don't recognize me! This chance encounter should live in infamy."

She laughed and he instantly liked the sound of her voice, even though he still had no idea who this cheerful woman was. He liked her cheerfulness too - it communicated good humor and friendly intentions but somehow managed not to slip into grotesque. He couldn't help but appreciate the masterful balancing act (eccentricity, so common 
and even cultivated among his old St. Petersburg acquaintances, was not his thing). And still, he couldn't remember her.

"Alright, alright," she patted him on the shoulder in a mockingly condescending gesture. "I'll help you out. Look, here," she tapped the bridge of her nose with an immaculately manicured index finger. "I used to have a unibrow - right here. You see? Like that Mexican painter, Frida Kahlo. Did you see the movie? No? You should, it's quite good!"

It was time for him to fake recognition but he couldn't, somehow he knew that this handsome, dark-haired woman (two perfectly trimmed black eyebrows belied the unibrow reference) would immediately call his bluff. She studied his face for a few seconds and sighed, now slightly annoyed:

"Come on, how many lives have you lived? Think: your junior high class, a new girl, transferred from Baku..."

And suddenly he remembered, more than remembered - he felt transported by some gentle but powerful force into that classroom, with a view on the canal. The classroom walls were painted an indistinct beige and displayed half-a-dozen portraits of the classics of literature; a Mayakovsky quote was plastered above the blackboard: "I would learn Russian simply because it was Lenin's language." It all came back to him now - the wet granite embankment outside the classroom window, the endless rainy afternoons, the rush of exhilaration, the sense of common purpose, the excitement, the feeling of disgust. Yes, he remembered now:

"Wait a minute .... Are you . . . are you . . Mariam?"

She made a quick show of demonstrating her relief: "Phew, finally! Of course, I am Mariam. The last name has changed - I lost it to my first husband, along with my virginity, you know . . . the usual. But the first name has sort of stuck with me." She smiled at him warmly, apparently they had moved past the teasing stage and towards a genuine reunion.

To his surprise, Mariam was aware of the general outlines of his post-high school life trajectory: the army, the first marriage, then emigration to Israel, then another move - to New York. She even knew that he had kept his apartment in the city and visited regularly from the States. How in the world did she know all of this? 
"Ah," she shrugged, "St. Petersburg pretends to be a major metropolis, but we all know that it's really but a small provincial town, where every bit of news travels fast and rumors - even faster."

No wonder he had some difficulty recognizing her. Somewhere along a twenty-yearlong stretch of the road she had shed more than the Kahlo-like unibrow and her Armenian last name. No trace of a cornered little ferret, scowling fretfully at her relentless pursuers. Her joviality seemed natural, he saw no signs of playacting: she appeared to be genuinely pleased — with a balmy June morning, with their chance encounter right outside the metro station, with her own ability to attract and command attention.

Momentarily, he shook off the interfering vision of a stuffy classroom in mid-afternoon and saw her as she was - an attractive brunette, assured of her powers. And she could read him too.

"An ugly duckling, my late grandma used to call me."

“Well, not anymore," he smiled.

"Nope," she shook her head, "Not anymore - the ugly duckling has grown and matured into an OK duck."

She was a doctor, a pediatrician, to be exact - with her own practice. In a city where after the Soviet collapse rank and status had come to define (and often ruin) personal relationships, she clearly passed the success test. Her daughter was . . . she was the same age as Mariam when they first met. Even more strangely, the daughter attended the same high school, which, as Mariam quickly explained to him, was now considered among the most prestigious in the city and catered mostly to the elite:

“The place is corrupt to the core. You wouldn't believe the bribes I had to dish out to get my daughter in. But the teachers are excellent. There are even a couple of holdovers from 'our time'."

To him, that 'our time' struck a discordant note: she claimed a shared history that, in fact, covered less than a year. Did she forget? Her harried mother had to withdraw her after that spring quarter. Did she forget? He couldn't tell. But he could tell that Mariam had a gift, and he wondered if it had anything to do with her professional occupation. The gift was a skill - a particular knack for initiating the stranger (sort of a stranger, in this case) into her world. Within a few minutes of the conversation he 
had developed a strange sense of familiarity that he experienced almost as a sense of déjà vu: their common past didn't have to be a fiction, their fluke late-morning encounter on Nevsky didn't have to be accidental.

That evening he was throwing a going away party that was intended to double as a real farewell - it was time to sell the apartment and finally put some distance between the corporeality of New York and this exhausted St. Petersburg fantasy. Would she care to stop by? She sounded delighted with the invitation, but she probably often sounded like that. Yes, she would, absolutely. How nice and spontaneous of him. Would it be appropriate to bring along her 'guy'? But of course, the more the merrier. He gave her the address - just a few blocks away, around the corner from the Catholic Church. The invitation made it easy to say good-byes - as usual, he had intuited a way to evade permanence. Indecisiveness - that's how Lisa identified that feature of his. Lisa was a definitions expert. Lisa was decisive. Lisa was many things . . . A quick pinprick, a momentary dimming of the morning light - just for a second, a split second, to be precise. He looked up - the tiniest of cumulus clouds had brushed by the edge of the sun disc but, as if burned by this proximity, instantly separated itself from the brightness and floated on - towards the gulf.

On his walk back to the apartment, he was compiling a mental list of items to buy for the party. He also thought of Mariam and how, for a few minutes, he experienced her life as his own. Those thoughts though didn't stay with him; the lazy morning was about to become much busier and he had other things to worry about: that shopping list, and the packing, and a phone call to the realtor. But Mariam . . . . One runs into people on Nevsky - the prospect, he read somewhere, was likely designed specifically for such happenstance. Running into her was not surprising. The surprising part was Mariam herself. Mariam has fared well and that simple thought filled him with relief. She has fared really well. Who would've thought . . . . That ugly duckling, that cornered hissing ferret... Will she come to the party? He considered the odds, weighed them carefully, and decided that she probably won't.

But she did. She came in late and alone. Of course, at the peak of the White Nights, the notion of late was relative to one's personal conception of time, and his tended to follow the never-setting northern sun. In case of Mariam, the notion 'alone' similarly assumed certain relative quality. He was mixing drinks in the kitchen and didn't hear her ring, and by the time he spotted her in the living room, Mariam had already established herself as the heart and soul of the party. Being the center of attention came naturally to her. 
Someone had placed a drink in her hand and now she was perched on the edge of a coffee-table, gyrating slowly to the music, laughing at something one of his guests, the fashionable conceptual poet Yegor, was eagerly whispering in her ear. Yegor was on his highest conquest alert but only the most alpha of the several other men, who like purposeful sharks circled the coffee table. She waved at him and made big eyes, indicating the hilariousness of this almost comical encirclement and mouthing a mock appeal for help: "SOS, I am completely surrounded!" He could see that she was in her element. She didn't need his help.

\section{$* * *$}

He remembered the very first impression, mostly because it captured an intense feeling that was at odds with his upbringing and previous life experiences. Their elderly physical education teacher, a wounded World War II vet, often referred to him (and others) as 'sheltered'. The teacher, a true man of the soil, resented his young urban charges, who had had the audacity to grow up in peacetime. "You don't know shit, you don't even know how to hate," he sometimes faulted them. For the veteran, the field of life was a field of battle, and all those devoid of martial instincts elicited his contempt. He enthusiastically cheered the invasion of Afghanistan, but not for any patriotic or geopolitical reasons. After the Soviet tanks rolled into Kabul he (correctly) concluded that now the 'soft asses' would finally learn what 'killing and getting killed' was like - somehow he believed that to be an essential educational experience. Sadly, his prediction would prove to be only too true for a number of his students . . . . But before Afghanistan had a chance to test some of them, most of them would be tested by Mariam, who was transferred to their high school at the beginning of the freshman year.

Years later, on those rare occasions when alcohol or a particularly poignant literary association prompted him to travel down memory lane, he wondered about the sources of that all-encompassing and eviscerating hatred that he felt towards a disheveled, black-haired girl with a unibrow. Her manner was both obsequious and unfriendly, servile and hostile at the same time. She transferred from a school in Azerbaijan and the rumor had it that her transfer had been the result of a near-death experience in a school yard, where Mariam, one of very few Armenians at her Baku school, was set upon by a bunch of local boys. Hearing that was hardly a surprise - being Jewish, even at this early age, he understood clearly the limitations of the vaunted 'friendship of the peoples'. Yet the harrowing story of Mariam's Baku ordeal somehow failed to make her a sympathetic character - on the contrary, it simply served to confirm her instant pariah status. 
His best friend Dimka thought she looked feral: "What a savage creature she is, just look at her - hideous, vicious, s-o-o-o ugly!"

And indeed, he couldn't stop looking at her: her beat-up woolen slippers, her brown stockings of rough cotton-full of unpatched holes and perpetually loose at the kneesher stained uniform blouse with an apron strip slipped down to the elbow, revealing the contours of an overdeveloped breast. The sight of that breast, unusual on a girl her age, made him anxious and fueled the desire to . . . To do what exactly? He was not quite sure but eventually came to believe that it was a desire to hurt, to inflict pain, to see this wild-eyed girl, her mouth distorted in a mad grin (a scream?), writhe in agony. The novelty, the intensity of these emotions overwhelmed him, but also made school infinitely more exciting. And he couldn't fail to notice that most of his friends, boys and girls, had a very similar response to Mariam. All of a sudden, the cliques, the insignificant rivalries and minor snubs were all but forgotten. Their shared hatred of the new Armenian girl unified them and there was sweetness in that unity. The warloving phys-ed teacher had nothing to worry about after all.

The taunting ensued within days, if not hours, of Mariam's appearance in their classroom. They mocked her 'southern' accent and made fun of her angular gait. One day most girls in class came to school sporting massive unibrows penciled in black. On their daily walks home from school, strolling up and down the tree-lined boulevard, Dimka and he concocted elaborate plans to better humiliate Mariam. All their creativity and the pulsating teenage energy went into this scheming. During that school year, they lived the most fulfilling, the most horrifyingly exciting months of their youth. Through trial and error, they learned to pace their attacks, they learned how to escalate, how to withdraw quickly only to return when they were least expected, how to besiege and wear out the besieged. Both of them hailed from bookish Jewish families and their familiarity with literature and artistic precedent came in especially handy. As the ringleaders of an ongoing assault they gained in popularity, a reversal of fortunes for which they were thankful. Never before had he felt so close to his peers, and he cherished the joy of being accepted on his own terms. Or so he thought.

Their harassment of Mariam grew progressively more physical in nature. This progression had its inevitable logic to it, and he recognized it as necessary, akin to the laws of physics they were learning during that Fall quarter. The first tentative kick in the hallway during recess proved to be tremendously satisfying. After school they spent hours on the boulevard, discussing the experience and analyzing its most minute details. Mariam's response to mistreatment was puzzling, but its very strangeness 
inspired them to further mischief. She defied expectations and, by acting unpredictably, greatly enhanced the entertainment value of the torment to which they subjected her daily.

It was a truly remarkable show, marked by surprising plot twists, punctuated by seemingly spontaneous flare-ups and dramatic lulls in action. Mariam vacillated between displays of extreme distress and over-the-top merriment. One moment she would be wailing hysterically - all red, her face smeared with tears and beads of sweat (tears?) clinging to the unkempt unibrow. But within minutes a bizarre transformation somewhere deep inside her would generate a bout of laughter. She would lash out against her tormentors, aiming to kick them in the groin, reaching out to scratch them, to gouge out their eyes with her dirty, gnawed nails. But just as they grew seriously worried (some sweetness in that fear too) about the ferocity of her response she would retreat into a hallway corner, covering her face with unwashed hands, whimpering pitifully, pleading for mercy.

All of this was exceptionally disorienting and ... extraordinarily exciting: the unpredictability, the depths of her humiliation, the exquisite cruelty of their assault, the implicit danger of going too far. Mariam's flair for the dramatic added to the intensity of those several months. On one particular occasion, Dimka, relentless in his ingenuity, dropped a plate of meatloaf and mashed potatoes (their standard school cafeteria fare) into Mariam's lap. The whole cafeteria went silent, students flocked around expecting a scene. And Mariam didn't disappoint. Scowling at the nervously expecting mob she scooped up a handful of the steaming mess from her lap and proceeded to methodically smear it all over her uniform, especially over the bulging breasts, and then all over her red and sweaty face. She sneered, seemingly uncontrollably. The mob was stunned, watching in disbelief this act of extreme selfabasement. How do you really confront someone who is willing to drink the chalice of humiliation to its dregs-covered rough bottom? His hatred of this strange, largebreasted Armenian girl couldn't be any more visceral, and at that moment he knew they would have to up their ante.

\section{$* * *$}

As so often happens at such parties the host had far less fun than the guests. He didn't mind, not really, but at some point it did register with him that he had barely left the kitchen. He walked down the corridor - most of the remaining guests (the crowd had thinned out considerably) hung out in the living room. He passed around the drinks and headed back into the kitchen. The guests protested and he promised to be back 
shortly. The door to the study was slightly ajar, he peeked in and saw Mariam reclined on the daybed next to the conceptual poet - they were energetically making out. The faded midnight light fell through the muslin drapes and rendered the scene an artificial and even borderline comical quality; he smiled to himself, and quietly closed the door. Over the years he has observed or participated in quite a few such scenes; for him, they were part of the White Nights canon - along with the echo-filled courtyard and the pallid sunlight penetrating through the parted drapes at midnight, along with the boozy companions, conceptual poets all, even those who were not. It was time to close that chapter and to make a decisive break (don't say a word, Lisa) with this chimera, which really was nothing but his past masquerading as an elusive and uncertain present. But first, he would have to wrap up the party and embrace his friends one last time, before locking up behind them and heading back to the kitchen to do the dishes. Before... heading back to New York.

Mariam leaned against the door frame, eyeing him with apparent amusement. He wondered how long she had been standing there. Doing dishes could be therapeutic for him - a perfect time to be lost in thought, or whatever passed for a thought at 2 am in late June, just before the restless sun would begin its morning ascent. She found the sight of him entertaining:

“How cute - doing dishes all alone. I can't tell you how touching this is to observe." He gave her a wan smile: "Where is the poet? I thought you were into him, no?" She touched the glass kitchen door with her forehead: "Oh, nice, feels so cool... The poet, you say? Yeah, I was... for a few minutes, but then he recited a couple of his poems and the spell was broken. It's a common St. Petersburg misconception that reciting poetry leads to a fuck. I mean, it may... occasionally, but then he should've done better than that." She stepped inside the kitchen and picked up a dish towel: "Here, let me help you, I'll dry the dishes." For a few minutes they remained silent, working in tandem. Her motions were quick and expert. Then she paused: "Do you think I'm promiscuous? You can be honest."

He looked at her confused: "Promiscuous? Why? Of course not. You're a grown up person and you do whatever you want to do. Who is to judge you?"

She considered his response for a few seconds and shrugged her shoulders - his openmindedness failed to satisfy her: "It's a nice thing to say but quite meaningless. It's an American thing to say too." 
He objected: "Now you're sounding accusatory. And I'm not really an American, not exactly."

"True, not exactly, but close enough... You know I had this teenage fantasy of sleeping with an American guy. I guess many of us did at the time. But it never happened. A German happened, a couple of Italians, even one Swede (which was a mistake), but not an American."

He made an effort to understand her, to follow her train of thought, but decided that he could do no better than reiterate his original response: "No, seriously, I don't find you promiscuous. Not at all. You're vivacious. My ex would've accused me now of using a cliché but . . . you know . . . your presence lights up the room. Zest for life as they say. Don't laugh, I actually mean it."

But she did laugh: "You're funny and . . . sweet. My grandma always said that I had a magnetic personality. Be careful, she would say, with that personal magnetism of yours." She rounded her eyes and changed her voice to an affected croak that brought to mind a Lord of the Rings movie: "I'm dangerous, young man, very dangerous."

Who was she? This being St. Petersburg she was likely a literary character or else pretending to be one. He rummaged his memory of their high school curriculum for an appropriate reference. One of those phantasmagorical tales by Gogol (They did run into each other on Nevsky prospect, didn't they?)? A Dostoyevskian feverish dream (The White Nights reigned indisputably just outside the kitchen window, did they not?)? But none of the references fit - Mariam's southern vitality, her 'zest for life' defied the rain-soaked St. Petersburg literary standard. She was in a league of her own - a woman apart.

Together they finished up drying the dishes. She placed the wet towel on the checkered oilcloth covering the kitchen table and looked at him expectantly:

"So what's next, my childhood friend?" Was she teasing him again? Challenging to come back with a joke?

He checked the wall clock - it was almost three in the morning and the short-lived night outside had already receded into memory. "I can call in a cab," he suggested cautiously, not quite knowing what was expected from him.

"You could," she agreed... most unhelpfully. With her manicured finger (the same one with which she had pointed out an absent unibrow) she drew an invisible whimsical 
pattern on the oilcloth. "Would it freak you out if I told you that I like you?"

"I like you too..."

His good manners seemed to annoy her and she dismissed them with a casual flip of hand: "Listen, you don't have to be so polite - I'm not used to it and, frankly, it gets old quick.” But almost immediately she relented: “Ok, sorry, I didn't mean to be brusque. It just sounded so... I don't know... so fake, I guess... I love you, honey - I love you too." She uttered the last line in a heavily-accented English, lampooning an imaginary American couple. And yet she came across serious enough but also somehow bewildered - as if caught off guard by her own frankness.

"I hate these nights without darkness," she continued after a short pause that he failed to fill. "I've lived in this city for most of my life now. You may not remember but my Russian used to be accented. I dropped that darn accent, those fucking soft consonants - the curse of the Caucuses - decades ago. I've never been back to Baku, certainly not back there - what sane Armenian would ever go back to that bloody oil rig? I'm not suicidal, you know . . . . So, that's it - a southern beauty coming into bloom under the gray skies of your precious Northern Venice. And, would you believe it, I still don't feel at home here, especially during this time of year, when the cursed city denies me even the most natural and easily obtainable thing in the world - a few hours of solid darkness. Just give me eight pitch dark hours - to rest, to make love with a stranger and afterwards pretend that nothing happened. It's easier to pretend in the dark, it's more expedient for forgetting ...."

He thought that it was exactly the opposite for him and then wondered if Mariam had not inadvertently stumbled onto a new fault line between the north and the south. For a second, it felt like a momentous insight on his part - a luminous flash of new understanding. But to keep up with Mariam one had to forgo the luxury of such theoretical detours.

“It'll probably feel incestuous," she said.

"What exactly?" he pretended not to understand.

She let out a tired sigh: "Oh, stop it. Can we not play these games now? You understood me perfectly well."

He fidgeted and busied himself with the folded kitchen towel. Why in the world did he fold it? It was still wet, and he must've spent a full minute looking for a perfect drying 
spot in an almost empty kitchen, before finally deciding to spread it across the radiator.

All along he felt Mariam's presence and knew that as soon as the towel conundrum has been solved he'd have an even more complicated one on his hands. "I'll call you the cab," he offered again, trying to sound as matter-of-factly as possible. She smiled condescendingly and he immediately became embarrassed of his own insincerity, he wished for an easy way out. You run into all sorts of people on Nevsky, and some of them, the dark-haired Caspian beauties, for example - the fully grown ducks of transplanted pedigree, are liable to offset your recently (and barely) restored life's balance.

“Don't be so tense," Mariam was standing right behind him now. Quietly she leaned into him, letting him appreciate the generosity of her body, its willingness to be available to him. On her own terms, she was giving him a way out. "You don't really have to call the cab," she whispered into his shoulder.

\section{$* * *$}

Following the outrage in the cafeteria, the school remained abuzz for weeks. Conflicting and often grotesquely exaggerated accounts of Mariam's awesome and horrifying performance spread through all the grades. After classes, he and Dimka spent hours on the boulevard - strategizing for an appropriate and appropriately fearsome response. Raising the ante indeed: the months of hounding of Mariam were set to culminate in an awe-inspiring grand finale - a meticulously choreographed coup de grâce, staged with a nod to their cinematic and literary influences of the moment. The school was gripped by anticipation and again he found himself at the center of attention - by a general consent it would fall to him to administer the final judgment. Vox Populi, Vox Dei - the people have spoken and, by popular acclamation, appointed two thirteen-year-old Jewish boys their honorary ambassadors and . . executioners. They were humbled and overwhelmed by the honor, but as befits the true stoics they embraced the challenge. Mariam's pain and symbolic destruction would be the price of their popularity.

The spring stirred late that year but once it did the telltale signs were everywhere. That spring had come off the pages of the Russian Literature textbook they were reading in class: the blackened patches of muddy snow, crusted into permanence around the rusted pole of the bus stop sign; the innocent rivulets, streaming down the boulevard, carrying with them the pathetic remnants of winter that had survived until April buried inside the snowbanks - the sundry little branches and twigs, the cigarette 
butts, the darkened dead leaves. The renewal was in the air, but first the city had to purge itself of its dead and dirty wintry secrets. Hence the rivulets of melting snow, transporting the ragged debris towards the sewage drains, hidden under the heavy manhole covers, or down the slope towards the canal. One evening his mother came back home from work in a particularly light-hearted mood, she was carrying a tiny bouquet of yellow mimosas, she was humming a lovely tune - the spring, she declared with her usual theatricality, had finally arrived.

Their school days on Fridays were bookended by a Chemistry class - a stale affair, taught by a perpetually bored-looking young woman, whose lack of enthusiasm for her subject rivaled that exhibited by her pupils. Under ordinary circumstances, the end-ofclass bell occasioned a virtual stampede by students, desperate to put some distance between their physical bodies and the glossy Periodic table, mounted on the classroom wall. But that Friday proved to be different - there was no crush for the exit. The students left the classroom in an orderly fashion and once outside almost immediately reassembled in a neat formation. A casual observer would've puzzled at such seemingly spontaneous expression of social cohesion. But the mob, as mobs sometimes do, had a purpose, it adhered to a script, which was intuited, not rehearsed. So many years later he could still remember the excitement of that assembly, he could see his friends' faces - open, eager and glowing with anticipation. What can be friendlier than a jubilant crowd at a public execution? The condemned is lavished with warmth and appreciation, her body in its coming agony will provide unprecedented entertainment to the masses, who will draw on the pending spectacle to affirm their own claim on living. They fully embrace this connection between another person's destruction and their own survival. They acknowledge and celebrate it.

It was clear to him that Mariam knew what was coming. Trapped inside the formation she acted with an uncharacteristic restraint. Some of his favorite books contained famous execution scenes and, strangely, they often captured a sense of serene resignation on the part of the doomed. When finally facing the executioner's ax, the nefarious and irresistible Milady de Winter of The Three Musketeers accepted the inevitable and bent a proud head to her pursuers' will. In Darkness at Noon, Arthur Koestler's Rubashov embraced his own execution as historically necessary - a fit of dialectical reasoning worthy of an old Bolshevik. Mariam was hardly familiar with these literary precedents, but she fell right into a well-trodden pattern. She walked silently (a dead woman walking), her feet in those oversized soiled slippers shuffling on the hardwood floor of the main hallway. She walked (was led) past the stinking gym, past the foul-smelling cafeteria, past the indifferent-looking Lenin statue - a tribute to 
another great dialectician, someone who had no trouble recognizing historical necessity.

The procession left the school building and marched on towards the soccer field in the back. And that's where Mariam's demeanor suddenly changed, or rather reverted to its usual ferocity. She was hissing, and spitting, and swearing at the spectators. With piercing howls she threw herself at her oppressors - again and again. But the phalanx didn't budge; he had never observed such a determination in the ordinarily immature faces of his school friends, those 'soft asses' par excellence. Like silent Spartan warriors, like wordless Zulu fighters, step by slow step, they reached the middle of the field, and only then their ranks broke, allowing them to retreat to the field's fenced edge. Mariam was left behind - spinning, and pacing, and hissing, and glowering, and cursing them in the foulest language. But he contemplated her without the usual disgust. He didn't hate her anymore.

A strange calm descended upon him - a great calm that came, he realized, with a great sense of responsibility. Just the two of them remained in the middle of that field, united in a script that, each one of them knew, could not be altered. Mariam's behavior underwent yet another change - her frenzy subsided and what was left of it had transformed into heavy panting. She looked disoriented, as if she were an actor who suddenly forgot her lines.

“What now?” she asked him, her voice rasping, annoyed. She was asking for guidance . $\ldots$

"What a strange girl," he thought. "What a weirdly strange girl . . . ." He explained to her what needed to be done (get down on your knees, lower down your head, don't move) and to his surprise she complied. He didn't feel entirely present at the scene but rather floated above it, overhearing someone who looked and sounded like him issuing orders to a red-faced, dark-haired girl with a unibrow.

That scene would come back to haunt him again. Not because it became a defining memory, but simply because he once saw it re-enacted on television. He was holed up at a conference hotel in Toronto, flipping through channels, and generally feeling depressed about the predictability of his life and career choices. CNN was running a special about the horrors of the Taliban rule in Afghanistan: the bearded morality police, riding armored-plated 'tacticals' with machine guns mounted on them - check, the destruction of the Buddahs of Bamiyan — check, the jolly crowds assembling in a soccer stadium... He sat up in bed, fearing to guess what was coming next. But it was 
all too obvious: a 'tactical' drove onto the soccer field and two bearded guards helped a third figure - a woman in a full blue burka-climb down the truck bed. The camera swept across the crowd, capturing the happy and expectant faces of men - young and old - and the children of both genders. The woman's pain will be their joy, her impending destruction will give them reason to live, her spilled blood will course through their veins and animate their bodies. The guards led the woman to a penalty kick spot and said something to her. She lowered herself on the ground - so compliant, so dutiful, so willing to oblige. Who was she? Someone that submissive... what had she done to deserve this? This penalty kick with a piece of lead? This rapt attention of a captive audience? The guards took a few steps back and cocked their AK$47 \mathrm{~s}$.... And that's when he heard himself scream. Desperately he fumbled for the remote, picked it up, dropped it, picked it up again, and finally managed to turn off the fucking CNN just as the guards pulled the trigger.

Respectful of the script, Mariam did as told. One couldn't wish for a better acting partner. Without so much as trying she exhibited a keen and natural flair for dramatic stagings. Her wild fluctuations - from timid acceptance to rage to bashful supplication - served to entertain. Even facing certain harm she continued to work for the audience, she insisted on working with it. Now safely stationary, folded in a prayer pose, Mariam kept herself close to the ground. He couldn't see her face but imagined it distorted by a frantic grin. Such a grin would've been appropriate for the occasion. So he thought as he embarked on a ceremonial jog along the field's perimeter. He held his fists high up in the air - in a Mohammad Ali style, so popular with them at the time. The crowd chanted its support. He felt the warmth of the April sun on his cheeks; he took in the sight of the fluttering sparrows - hovering over the canal, celebrating the arrival of spring. The crowd chanted its love - for him, for the late and muchanticipated spring, even for Mariam, who remained motionless in the middle of the pitch. He completed the circle of honor and positioned himself at a distance of some twenty meters from the folded heap that was his classmate. The time for action had arrived, it arrived along with the seasonal warmth and the happy sparrows ducking in and out of the lilac bushes along the canal. He would administer justice, he would administer a penalty kick for the ages. He was rumbling in the jungle, he was Mohammad Ali dispatching George Foreman, he was the mysterious and honor-bound Count de la Fère of The Three Musketeers fame, condemning his beloved to death.

The time held still as he sprinted across the dusty patch towards Mariam. Not a great athlete he had never run before as fast or (Dimka would assure him afterwards) as gracefully. It was important not to slow down, not to ruin the carefully choreographed 
ritual by a last-minute slip-up or stumble. He kicked. The exact moment of the impact didn't register with him but, in slow motion, he observed Mariam jerk forward and roll sideways - her arms and legs flailing. The consummate performer to the very end, she kept on rolling, and rolling, and rolling, until coming to an abrupt rest against the rusty goal post. He finally saw her face again - flushed and sweaty as always, its features distorted by a primordial scream. What a triumph! He notched this one up for his friends, for their love and acceptance on this radiant April afternoon. He notched this one up for their sense of togetherness and purpose. Mariam may have failed to appreciate it at the moment - understandably so. Wringing in pain and humiliation, wiping off her tears, inspecting the torn sleeve of her tattered school uniform, tapping tentatively at the raw gash on her elbow, Mariam was in no position to recognize the value of his sacrifice. He notched this one up for her too. He thought that maybe in a week or two, in a month - he would be able to explain all this complexity to her. He would have to make sure that she remains calm and doesn't succumb to one of her frightening fits of fury. He'll explain to her the historical necessity of his act, its ultimate logic. The law of physics. She will understand. She should be able to understand . . . .

Only they didn't have another chance to talk. A few days after the historic 'penalty kick' Mariam's mother withdrew her daughter from school. The head teacher explained to class that Mariam was never a 'good fit'. The students agreed.

\section{$* * *$}

She kicked off the crumpled sheet and having thus liberated her body stretched with obvious pleasure. “Oh, Mariam,” she yawned. “Oh, Mariam, you slut. You did it again. And with a childhood friend no less. What would your grandma say? Your black kerchief-wearing and Catholicos-worshipping grandma?" "Shameless, so utterly shameless," she parodied her imaginary grandma's heavily-accented croak.

Mariam got out of bed and walked over to the window, only to pause momentarily in front of the window sill before, with a dramatic jerk, drawing open the curtains. He couldn't help but notice how comfortable she was with her own nakedness. For a couple of minutes she studied the courtyard down below, then issued a diagnosis: "Your typical St. Petersburg courtyard - pretty dreary-looking, if you ask me, even during this time of year." She turned around and eyed him quizzically: "I just had this weird vision, right now. A moment ago I saw you crossing the courtyard. A sickly Leningrad boy... You know, you all looked like goldfish to me, very vulnerable, worthy of my pity. In your silly blue uniform, your stupid school attaché case in hand. 
Remember, those used to be all the rage back then. They looked like bricks bound in leather. Probably just as heavy. What did you call them? Diplomats! That's it diplomats! And carrying it you certainly looked like one. An important diplomat on his way to school. Bus no. 6, right?” He nodded, mesmerized by her performance, but also by her silhouette against the light that had flooded in through the parted curtains.

"You are shameless," he said quietly. It was a compliment and she received it as such.

It was almost eleven now. Mariam came out of the shower and dressed quickly. She asked him to walk her to the metro station. No, forget about the cab. Apparently you've never heard about the latest natural phenomenon at this degree of northern latitude - it's called St. Petersburg traffic. She had to be in the office by noon, no cab would be able to cross the town in under an hour. Forget about it. Let's walk . . . . And they did. They crossed the courtyard and he put up a little show for her sake swinging in front of her an imaginary diplomat, adjusting an invisible school uniform. They walked out onto the street, which was choked with traffic but somehow still felt desolate. They passed the old bus stop - no. 6 had stopped running years ago but the authorities never bothered to remove the dilapidated yellow sign. They pretended they were waiting for a bus, the no. 6 bus to carry them to school.

"What a pity it's not coming," she smiled.

"It must've broken down, never left the depot," he joked. She shrugged. She smiled. She took his hand when they were crossing the street but once on the other side forgot to let it go. They kept on walking holding hands, and that added intimacy felt appropriate to the occasion.

"Your hand is soft," she informed him.

For a second he was taken aback and protested: "Why soft? It shouldn't be soft. How can it be soft? After all the hours in the gym?"

She pecked him on the cheek: "No need to get all worked up about it. It's just a comment. And don't you worry - I've noticed your body, actually gave you a quick professional examination while you were asleep. I am a doctor after all. It's pretty hot. ALL of it. You have nothing to worry about. And your hands . . . . They are not rough, not calloused. They are like a reflection of your inner self - gentle is the word. You're a gentle man, my childhood friend - a little goldfish that jumped out of the fish tank." 
He noticed that they had reached the very spot where she first approached him the previous day. Mariam laughed:

“My, my, my... how symbolic indeed. It's like we've closed a full circle within... she checked her watch... almost exactly twenty-four hours. Do you believe in numerology? I don't." Yes, just twenty-four hours. Or twenty years. Or choose your own number and imbue it with meaning, turn it into an artefact. "Will you write to me?" She sounded matter-of-factly, not anxious at all. Nothing heavy about her touch - it was a light touch indeed.

"But of course!" he came across too eager to please and she instantly caught on to it. “Oh, come on... Just say yes - like in 'yes, I will write to you'. Drop the 'of course' — no one was asking for it."

"Yes, I will write to you..."

"You see, that's much better, more natural, no peer pressure as they say."

By the station entrance, she spent some time kissing his face, avoiding his lips but compensating for this oversight by planting numerous quick kisses on his cheeks, his forehead, his neck, his eyes, even the smooth earlobe.

"I’m kissing you into oblivion," she explained somewhat mysteriously.

Not much of an explanation really, he would have to consider it later. But not now. Now they needed to say good-byes. He detested the ritual. Another late start to another day, one of his last in this exhausting city that refuses to let him go, that keeps him tethered to his own shadow. Goodbye, Mariam. I can't tell you how lucky I am to have run into you. You made my day and you most certainly made my night. I just hope it was good for you, I hope it was worth it . . I hope . . . She looked at him with a hesitant curiosity, she brought his hand up to her face and pressed it against his palm, she kissed it tenderly.

"It was worth it," she said. "It was wonderful. And you know what the best part was?" She was being playful again - she had to be before separating herself from him for good. One is expected to cut her earthly connections before descending deep into the metro. And that's what she did - with a tease, with a wink, with an impish retort to her own rhetorical question: "It didn't hurt, my darling, not at all." 
Maxim Matusevich is a historian of Africa and the Cold War. Born in St. Petersburg, Russia, he moved to the United States on the eve of the Soviet collapse. He is presently Professor of Global History at Seton Hall University in New Jersey, where he directs the Russian and East European Studies Program. Maxim also writes and publishes fiction, mostly in English, but occasionally in his native Russian. His short stories and essays have appeared in the Kenyon Review, New England Review, the Bare Life Review, MumberMag, Anti-Heroin Chic, BigCityLit, the Wild Word, Transitions, ReLevant, and other outlets.

Michael ('Misha') Goro is a painter, printmaker, and educator, who has lived and worked in Russia, Europe, Israel, and the United States. Born in St. Petersburg, Russia, he received his MFA in printmaking at the University of Illinois at UrbanaChampaign. Misha presently serves as Chairperson of the Graphics Department at the American Academy of Art in Chicago. His works can be found in numerous private and public collections and have received a number of prestigious international awards in Japan, Korea, China, UK, Italy, and the United States. 